\title{
KONSEP TOTAL QUALITY MANAGEMENT DALAM PENGEMBANGAN KURIKULUM PENDIDIKAN ISLAM
}

\author{
Sagaf S.Pettalongi \\ STAIN Datokarama Palu, Jl. Diponegoro 23 Palu \\ e-mail: saggaf_1p4m@yahoo.co.id
}

\section{Abstract}

Curriculum is one of such vital important instruments in developing an educational institution that it should be designed in an effective manner in order to describe both direction and goal to be realized in Islamic education. A good curriculum is that which accommodates and meets community's needs and their environments, that is, having relevance and orientation to customers' need in education and job opportunities. To achieve this goal, educational institutions have to incorporate total quality management principles whose main emphasis is totally on satisfying services to customers' needs.

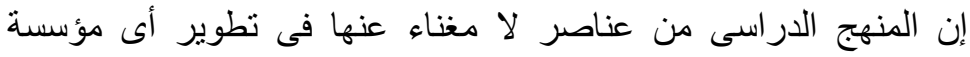

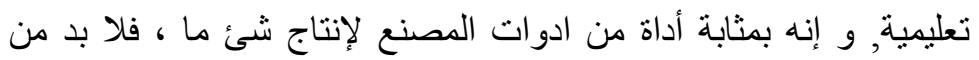

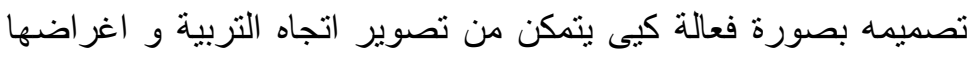

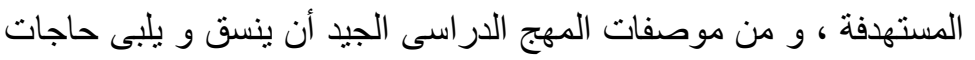

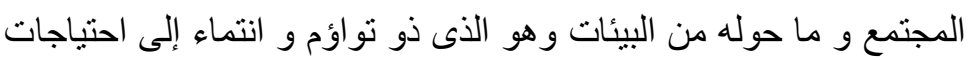

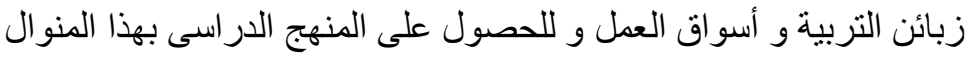

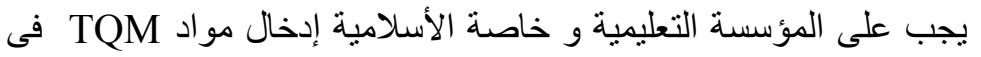

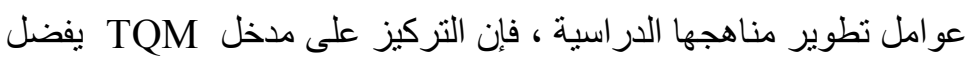

$$
\begin{aligned}
& \text { دائما خدمة الزبائن و احتياجاتهم الملموسة. }
\end{aligned}
$$

Kata Kunci: Total Quality Management, kurikulum pendidikan Islam 


\section{PENDAHULUAN}

Kurikulum merupakan bagian terpenting dari sistem pendidikan Islam, yang keberadaannya telah ada sejak awal keberadaan pendidikan Islam yaitu pada masa Rasulullah saw. Kurikulum pada masa itu berupa membaca, menulis dan syair Arab (Shalabî, 1954:16).

Seiring dengan perkembangan pendidikan Islam, terutama ketika pendidikan Islam dilaksanakan dalam bentuk formal, kurikulum pada lembaga-lembaga pendidikan Islam mengalami perkembangan yang puncaknya pada masa klasik pertengahan. Kurikulum lembaga-lembaga pendidikan Islam pada masa itu meliputi matematika (aljabar, geometri), sains (kimia, fisika dan astronomi), ilmu kedokteran (anatomi, pembedahan, dan farmasi), filsafat (logika, etika dan metafisika), kesusastraan, ilmu-ilmu sosial, hukum, sosiologi, psikologi, theologi serta studi Alquran dan hadis (Nakosteen dalam Sabda, 2006:2).

Dengan demikian, tampak bahwa pada masa klasik pertengahan, lembaga-lembaga pendidikan Islam telah memiliki kurikulum yang memuat sejumlah ilmu pengetahuan yang boleh disebut lengkap, meliputi ilmu-ilmu keagamaan (syariah) dan ilmu-ilmu alam (kauniyah).

Satu hal yang perlu mendapat perhatian terhadap kurikulum lembaga pendidikan Islam pada masa itu, yaitu adanya keterpaduan antara pelajaran atau ilmu-ilmu agama dengan ilmu-ilmu umum dengan tanpa ada pemisahan. Walaupun terjadi pengklasifikasian atau pemilahan ilmu pengetahuan umum dan keagamaan seperti dilakukan oleh al-Farabi, al-Gazali dan para filosof lainnya, para filosof menganggap bahwa semua ilmu pengetahuan umum harus dipelajari dan dikuasai karena ia merupakan bagian dari khazanah ilmu-ilmu Islam dalam rangka pengabdian pada Allah swt. (Sabda, 2006:2). Dalam Alquran Allah berfirman (Q.S Al-Zumar [2]):9).

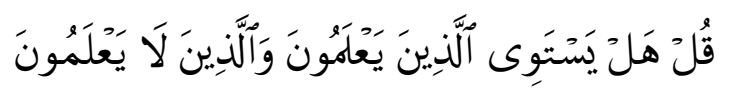

Terjemahnya:

Katakanlah apakah sama antara orang-orang yang mengetahui dengan orang-orang yang tidak mengetahui.. 
Konsep keterpaduan antara ilmu keagamaan dan ilmu-ilmu umum seperti awal Islam sampai pada masa klasik pertengahan perlu digagas kembali guna mengangkat supremasi ajaran Islam sebagai agama yang universal. Adanya dikotomi ilmu keagamaan dan ilmuilmu umum dewasa ini, bahkan dikotomi secara institusional yakni pemisahan lembaga pendidikan umum dengan lembaga pendidikan keagamaan (Islam) telah berimbas pula pada penyiapan dan pengadaan tenaga pendidik di sekolah-sekolah, sehingga guru umum hanya bisa mengajar mata pelajaran umum dan tenaga pendidik agama yang hanya bisa mengajarkan pelajaran keagamaan. Menurut Rahman (1982:130-131) ada dua pola yang pernah dilakukan oleh beberapa negara muslim untuk menengahi hal tersebut yaitu (1) menerima pendidikan sekuler modern sebagaimana telah berkembang secara luas di barat dan mencoba untuk mengislamkannya dengan cara mengisi dengan konsep-konsep tertentu dari Islam dan (2) menggabungkan atau memadukan cabang-cabang pengetahuan modern dengan cabangcabang pengetahuan keislaman tradisional yang diberikan secara bersama-sama disuatu lembaga pendidikan Islam.

Keterpaduan pola pendidikan yang diinginkan tersebut mungkin mirip dengan apa yang telah dilaksanakan pada beberapa lembaga pendidikan Islam di Indonesia, seperti perubahan Institut Agama Islam Negeri (IAIN) menjadi Universitas Islam Negeri (UIN) dan juga beberapa pondok pesantren modern lainnya.

Undang-Undang Nomor 20 Tahun 2003 tentang Sistem Pendidikan Nasional juga telah mengakomodir hal tersebut dengan adanya pemberian kesetaraan dan kesamaan dalam hal kurikulum pendidikan umum dengan kurikulum lembaga pendidikan Islam (SD/MI, SMP/MTs, SMA/MA) (Depdiknas, 2004:9), sehingga luaran dari satuan-satuan pendidikan ini dapat diterima pada jenjang yang sama pada sekolah-sekolah umum maupun madrasah.

Kesamaan dan kesetaraan status dan kurikulum pendidikan umum dan pendidikan keagamaan, menjadi semakin jelas arah dan tujuan dari lembaga-lembaga pendidikan Islam, yaitu ikut mewujudkan tujuan pendidikan nasional yakni untuk berkembangnya potensi peserta didik agar menjadi manusia yang beriman dan bertakwa kepada Tuhan Yang maha Esa, berakhlak mulia, sehat, berilmu, cakap, kreatif, mandiri dan menjadi warga negara yang demokratis serta bertanggung jawab (Depdiknas, 2004:9). 
Sebagai lembaga pendidikan yang bercirikan Islam, kurikulum pendidikan Islam diharapkan bisa mengakomodir pengetahuan tentang ilmu-ilmu umum disatu pihak dan pengetahuan ilmu-ilmu agama dipihak lain, sehingga kelak dapat menciptakan lulusan yang diharapkan masyarakat, yakni memiliki kemampuan dibidang agama dan juga memiliki kemampuan pada ilmu-ilmu umum. Oleh karena itu, konsep pengembangan kurikulum pada lembaga pendidikan Islam seharusnya selalu diorientasikan kepada yang menjadi kebutuhan masyarakat (pelanggan).

Pengembangan kurikulum yang berorientasi kepada kebutuhan masyarakat (pelanggan) merupakan konsep dasar dari Total Quality Management (TQM), yakni suatu model gagasan pengembangan kurikulum yang berorientasi pada kualitas). Dalam kaitan dengan hal tersebut tulisan ini mencoba menggagas sebuah telaah konsep pengembangan kurikulum yang berorietasi pada pasar dengan mengedepankan aspek mutu (kualitas).

\section{PEMBAHASAN}

Pengelolaan dan pengembangan lembaga pendidikan di Indonesia diarahkan pada tujuan yang sama yaitu mewujudkan Standar Nasional Pendidikan (SNP) termasuk lembaga pendidikan Islam, yang meliputi : standar isi, standar proses, standar kompetensi lulusan, standar pendidikan dan tenaga kependidikan, standar pendidik dan prasarana, standar pengelolaan, standar pembiayaan dan standar penilaian pendidikan (Depdiknas, 2005:67). Setiap lembaga pendidikan perlu meningkatkan kualitasnya dengan merujuk pada standar nasional pendidikan sebagai acuan kurikulum dan dilakukan secara berencana dan berkala dalam rangka mewujudkan tujuan pendidikan nasional (Mulyasa, 2003:9).

Optimalisasi pencapaian tujuan-tujuan diatas memerlukan pendekatan dan pengelolaan tertentu dalam mengembangkan kurikulumnya, sehingga kualitas lembaga pendidikan Islam dapat terus ditingkatkan. Total Quality Manajemen sebagai manajemen kualitas perlu diimplementasikan dalam pengembangan kurikulum lembaga pendidikan Islam. Beberapa pilar utama TQM yang dapat diimplementasikan kedalam pengembangan kurikulum pendidikan Islam, meliputi atas fokus pada pelanggan, keterlibatan total, pengukuran hasil, komitmen dan perbaikan terus menerus (Arcaro, 1995:11-14). 
Dalam pengembangan kurikulum secara nasional yang mengacu pada Badan Standar Nasional Pendidikan (BSNP) telah menetapkan 8 (delapan) aspek pendidikan yang harus distandarkan. Walaupun saat ini telah dirampungkan dan siap dilaksanakan baru dua standar, yaitu standar isi dengan peraturan menteri pendidikan nasional nomor 22 tahun 2006, dan standar kompetensi lulusan (SKL) melalui peraturan menteri pendidikan nasional nomor 23 tahun 2006 serta peraturan menteri pendidikan nasional nomor 24 tahun 2006 tentang pelaksanaan standar isi dan standar kompetensi lulusan. Demikian juga panduan penyusunan kurikulum yang dibuat oleh Badan Standar Nasional Pendidikan (BSNP) (Depdiknas, 2007:70). Selanjutnya setiap satuan pendidikan diharapkan dapat mengembangkan kurikulum yang diimplementasikan pada satuan pendidikan masingmasing.

Pengembangan kurikulum nasional dan penjabaran serta penyusunannya pada Tingkat Satuan Pendidikan (KTSP) adalah bentuk komitmen terhadap kebutuhan pelanggan (masyarakat dan daerah) dengan melibatkan semua komponen yang ada pada satuan pendidikan mulai dari kepala sekolah, para tenaga pengajar dan stakeholders lainnya.

Untuk mewujudkan total quality dalam lembaga pendidikan Islam, implementasi pilar $T Q M$ dalam pengembangan kurikulum perlu menjadi pertimbangan dan perhatian serius. Pilar-pilar TQM tersebut adalah:

\section{Pertama, Fokus pada Pelanggan}

Memuaskan harapan pelanggan berarti mengantisipasi kebutuhan pelanggan pada masa datang. Sekolah perlu mengembangkan fokus kualitas, setiap orang dalam sistem sekolah mesti mengakui bahwa setiap output lembaga pendidikan adalah kostumer (Arcaro, 1995:11). Kurikulum yang disusun harus dapat mengakomodir perkembangan masyarakat dan kemajuan ilmu pengetahuan dan teknologi. Oemar Attoumi al-syaibani (1979:520522) mengemukakan bahwa pengembangan kurikulum pendidikan Islam perlu memperhatikan prinsip-prinsip landasan pengembangannya yaitu:

- prinsip pertautan yang sempurna dengan ajaran Islam;

- prinsip tujuan universal dari materi yang dituangkan dalam kurikulum;

- prinsip keseimbangan relatif diantara tujuan dan isi kurikulum; 
- prinsip keterkaitan antara isi kurikulum dengan bakat, minat, kemampuan dan kebutuhan peserta didik, baik dalam hubungan dengan alam fisik, psikis dan sosial;

- prinsip pemeliharaan perbedaan diantara individu peserta didik;

- prinsip perkembangan dan perubahan;

- prinsip pertautan antara mata pelajaran, pengalaman dan aktivitasaktivitas yang terkandung dalam kurikulum.

Pengembangan kurikulum lembaga pendidikan Islam dengan fokus pada kebutuhan masyarakat (pelanggan) diharapkan dapat menghasilkan lulusan yang dibekali pengetahuan keahlian dalam agama sekaligus keduniaanya (Hasibuan, 2004:136). Oleh Karena itu, lembaga pendidikan Islam akan dikatakan baik dan efektif jika lembaga pendidikan itu mencapai tujuannya dengan melahirkan lulusan yang berkualitas sesuai dengan harapan pelanggan atau masyarakat (Arcaro, 1995:54). Harapan masyarakat terhadap kurikulum lembaga pendidikan Islam adalah lahirnya kurikulum yang dapat memberi kompetensi peserta didik pada bidang keilmuan secara umum dan juga penguasaan bidang keagamaan.

\section{Kedua, Keterlibatan Total}

Prinsip TQM dalam pengembangan kurikulum adalah setiap orang harus terlibat dalam transformasi kualitas. Manajemen mesti memiliki komitmen untuk menfokuskan pada kualitas, harus mendorong staf dan peserta didik untuk mengubah cara kerja lama kepada cara kerja baru. Perubahan Kurikulum Berbasis Kompetensi (KBK) kepada Kurikulum Tingkat Satuan Pendidikan (KTSP) adalah bentuk mengubah cara kerja baru, dimaksudkan agar semua komponen dalam lembaga pendidikan ikut terlibat secara aktif dalam operasionalisasi lembaga pendidikan, pemberdayaan warga sekolah (pimpinan, tenaga administrasi, tenaga pendidik dan peserta didik) (Hasibuan, 2004:136). Dengan demikian mereka dapat mengetahui informasi kesenjangan atau kebutuhan yang menyangkut tentang diri mereka. Berdasarkan kondisi tersebut, semua komponen dapat berperan dalam mengusulkan rencana-rencana kegiatan yang seharusnya dilaksanakan.

Secara struktural dari pimpinan tertinggi sampai tingkat bawah bisa berfungsi untuk memberdayakan semua potensi yang dimiliki oleh warga sekolah sehingga program-program kerja yang tumbuh dan berkembang dari sekolah dapat dilaksanakan. 
Keterlibatan total dalam konteks pengembangan kurikulum berarti inisiatif pengembangan datangnya bisa dari bawah seperti guru, orang tua peserta didik atau masyarakat sekitar (stakeholders), dan semua pihak itu memberikan secara penuh kemampuan yang dimiliki dan pelayanan yang optimal untuk mewujudkan kualitas yang diharapkan bahkan melebihi permintaan pelanggan (kostumer) baik internal maupun eksternal (Arcaro, 1995:78). Pihak atasan (pimpinan) selalu memberikan bimbingan dan dorongan. Untuk memantapkan konsep pengembangan yang dirintisnya dan dapat dilakukan lokakarya atau rapat terpadu guna mencari input yang diperlukan. Konsep TQM menghendaki agar kurikulum dikembangkan dengan melibatkan semua unsur yang terkait dengan suatu lembaga pendidikan baik secara internal kelembagaan maupun secara eksternal (stakeholders).

\section{Ketiga, Pengukuran}

Dalam pengembangan TQM, pengukuran merupakan salah satu langkah yang penting dalam proses manajemen. Secara tradisional ukuran kualitas atas luaran lembaga pendidikan Islam adalah prestasi peserta didik. Ukuran dasarnya adalah hasil ujian baik Ujian Sekolah (US) maupun Ujian Nasional (UN). Jika hasil ujian bertambah baik, maka kualitas pendidikan dikatakan juga membaik. Para pengelola lembaga pendidikan Islam harus belajar untuk mengukur kualitas, mulai dari proses pengumpulan data dan analisa data diperlukan sehingga dapat mengukur dan menunjukan nilai tambah dan perubahan kualitas yang dicapai (Arcaro, 1995:13).

Jika kualitas dapat dikelola, maka kualitas juga harus dapat diukur (measurable). Kualitas juga merupakan keunggulan (excellence) atau hasil yang terbaik (the best). Untuk mengejar kualitas, kesalahan harus dieliminir untuk mencapai keunggulan kompetitif lulusan suatu lembaga pendidikan, dan keunggulan komparatifnya dengan yang lain sesuai dinamika pasar tenaga kerja.

\section{Keempat, Komitmen}

Implementasi manajemen kualitas dalam lembaga pendidikan Islam diperlukan komitmen terhadap kualitas dan perbaikan kualitas. Total kualitas pendidikan adalah suatu perubahan budaya organisasi sebagai cara baru bagi kehidupan setiap orang. Sebelum seseorang akan melakukan perubahan, mereka harus percaya bahwa pimpinan 
tertinggi suatu lembaga pendidikan berkewajiban untuk mencapai budaya kualitas. Hal ini menuntut dewan sekolah dan administrator untuk menggunakan dan mengaplikasikan elemen-elemen dan prinsip TQM pendidikan (Arcaro, 1995:13).

Untuk memberikan komitmen pada kualitas, ada beberapa langkah yang perlu diperhatikan dalam menerapkan TQM yaitu:

- mempelajari dan memahami TQM secara menyeluruh;

- memahami dan mengadopsi jiwa dan filosofi untuk perbaikan terus menerus;

- menilai jaminan kualitas saat ini dan program pengendalian kualitas;

- membangun sistem total kualitas;

- mempersiapkan orang-orang untuk perubahan, menilai budaya kualitas sebagai tujuan untuk mempersiapkan perbaikan, melatih orang-orang untuk bekerja pada suatu kelompok kerja;

- mempelajari teknik untuk mengatasi akar persoalan (penyebab) dan mengaplikasikan tindakan korektif dengan menggunakan teknikteknik alat $T Q M$;

- menetapkan prosedur tindakan perbaikan dan menyadari akan keberhasilannya;

- menciptakan komitmen dan strategi yang benar tentang total kualitas oleh pemimpin yang akan menggunakannya;

- memelihara jiwa total kualitas dalam penyelidikan dan aplikasi pengetahuan yang amat luas (Field, 1993:13).

Aplikasi konsep TQM dalam prosedur pengembangan kurikulum berarti memaknai bahwa setiap langkah-langkahnya selalu diorientasikan pada kebutuhan pelanggan dengan mengedepankan aspek kualitas pada semua input dan prosesnya. Komitmen kualitas dibangun mulai dari level pimpinan tertinggi sampai pada level terbawah.

\section{Kelima, Perbaikan Berkelanjutan}

Konsep dasar kualitas adalah segala sesuatu dapat diperbaiki. Kualitas didasarkan pada konsep bahwa setiap proses dapat diperbaiki dan tidak ada proses yang sempurna. Menurut filosofi manajemen baru, bila tidak rusak, perbaikilah, karena jika anda tidak melakukannya orang lain pasti melakukannya. Inilah konsep 
perbaikan terus menerus. Perbaikan berkelanjutan berarti sesuatu yang belum pernah dilakukan, suatu tindakan pengejaran atas kualitas, prosesnya harus secara terus menerus diperbaiki dengan diubah, ditambah, dikembangkan dan dimurnikan (Saifuddin, 2002:37).

Lembaga-lembaga pendidikan Islam tidak cukup hanya menawarkan program studi atau sejumlah jurusan dengan kurikulum tertentu, kemudian orang tua dan pelajar menjadi puas. Akan tetapi lembaga pendidikan Islam harus menyediakan alat dan sumber belajar dan mengajar yang relevan dengan perkembangan zaman untuk mendukung kemajuan proses pembelajaran. Gedung sekolah dan sarana prasarana pembelajaran, pelayanan yang prima terhadap peserta didik, guru, orang tua dan masyarakat, serta lingkungan pendidikan yang kondusif. Kesemuanya ini akan memberikan kontribusi positif bagi kualitas proses dan kualitas produk (lulusan) lembaga pendidikan Islam.

\section{PENUTUP}

Salah satu pendekatan untuk meningkatkan kualitas pendidikan Islam adalah menerapkan $T Q M$ ke dalam pengembangan kurikulum lembaga pendidikan Islam, beberapa alasannya antara lain :

- Kurikulum bagi pendidikan adalah produsen, banyak masalah yang perlu diselesaikan dalam lembaga pendidikan Islam terutama kurikulumnya, agar pelanggan (konsumen) bisa tetap menjadikan pendidikan Islam sebagai alternatif dalam menyekolahkan anaknya.

- Organisasi lembaga pendidikan Islam dapat dijadikan model organisasi pengajaran yang tepat untuk semua, baik pendidikan tingkat dasar, menengah maupun pendidikan tinggi, agar bisa menghasilkan luaran yang berkualitas.

- Masih banyaknya problem yang hanya mungkin diselesaikan dengan membenahi kualitas lembaga pendidikan dan mengintegrasikan $T Q M$ ke dalam lembaga pendidikan Islam, terutama jika disadari bahwa sistem yang ada sekarang belum bekerja dengan baik sehingga belum memberikan kualitas yang diharapkan. 


\section{DAFTAR PUSTAKA}

Al-Syaibani, Oemar Attomi. 1979. Falsafah Pendidikan Islam. Alih Bahasa oleh Hasan Langgulung. Jakarta: Bulan Bintang.

Arcaro, Jerome S. 1995. Quality in Education: An Implementation Handbook, St. Lucie Press,.

Departemen Agama RI. 1982. Alquran dan Terjemahannya. Jakarta : Proyek Pengadaan Kitab Suci Al-Qur'an Depag RI.

Departemen Pendidikan Nasional RI. 2004. Undang-Undang Nomor 20 Tahun 2003 tentang Sistim Pendidikan Nasional. Jakarta: Dirjen Bagais.

Departemen Pendidikan Nasional RI. 2005. Peraturan Pemerintah RI Nomor 19 Tahun 2005, tentang Standar Nasional Pendidikan. Jakarta: Diknas.

Field, Joseph C., 2000. Manajemen Mutu Terpadu dalam Pendidikan, Konsep, Strategi dan Aplikasi. Terjemahan oleh Syafaruddin. Jakarta: PT Grasindo.

Hasibuan, Lies. 2004. Melejitkan Mutu Pendidikan: Refleksi, Relevansi dan Rekonstruksi Curriculum. Jambi: SAPA Project.

Rahman, Fazlur. 1982. Islam and Modernity Transformation of an Intelectual Tradition. Chicago: Chicago University.

Mulyasa, E. 2003. Kurikulum Berbasis Kompetensi, Strategi dan Implementasi. Bandung: Remaja Rosdakarya.

Sabda, Saifuddin. 2006. Model Kurikulum Terpadu Iptek dan Imtaq. Jakarta: Ciputat Press.

Syalabi, Ahmad. 1954. History of Muslim Education. Beirut: Al-Kasysyaf. 